the relatively small number of Asian children with active tuberculosis. The further analysis of our data by Dr Vickers is valid, but does not detract from our conclusion that tuberculosis was more common in poor children than in Asian children.

\section{Ribavirin in respiratory syncytial virus infection}

Sir,

Over the winter of 1988, 10 infants with congenital heart disease were treated for severe bronchiolitis at Guy's Hospital. All required respiratory support of greater than $50 \%$ oxygen in a headbox, and seven required assisted ventilation. Seven patients were positive for respiratory syncytial virus, and seven received nebulised ribavirin for three to five days. There were four deaths, all infants with pre-existing pulmonary hypertension (see table).

Despite the early use of nebulised ribavirin, supervised by Brittania Pharmaceuticals Ltd, some patients continued to deteriorate. Only three patients showed some improvement after ribavirin use. No patient improved when ribavirin was first used after ventilation had commenced. Indeed one child had an unexplained cardiorespiratory collapse on the ventilator shortly after starting ribavirin. We documented no other possible side effects.

We wish to emphasise the severity in Britain of respiratory syncytial virus bronchiolitis in infants with congenital heart disease. The high mortality in the presence of pulmonary hypertension confirms earlier American reports. ${ }^{1}$ Our clinical impression was that ribavirin, started very early in the disease 'may' prevent some infants progressing to respiratory failure. The outcome was never one of dramatic clinical improvement.

The resource implications of widespread early use of ribavirin in all mildly symptomatic infants are very great however (approximately $£ 600$ for a three day course). We therefore strongly support the call for randomised controlled trials of ribavirin in bronchiolitic infants with cardiopulmonary disease. ${ }^{2}$

\section{References}

1 MacDonald NE, Hall CB, Suffin SC, Alexson C, Harris PJ, Manning JA. Respiratory syncitial virus infection in infants with congenital heart disease. $N$ Engl J Med 1982;307:397-400.

2 Isaacs D, Moxon ER, Harvey D, et al. Ribavirin in respiratory syncitial virus infection. A double blind placebo controlled trial is needed. Arch Dis Child 1988;63:986-7.

M Sharland, N Whitehouse, and S Qureshi Guy's Hospital, St Thomas Street, London SE1 9RT

\section{Lung function and bronchial responsiveness measured by forced oscillometry after bronchopulmonary dysplasia}

Sir,

We were interested to read the recent report by Duiverman et al on lung function in the long term survivors of bronchopulmonary dysplasia. ${ }^{1}$ Their results differ from those of previous small studies and one large series ${ }^{2}$ in that they failed to find an increase in airway responsiveness to inhaled histamine. Although differences in protocols and techniques used in these studies make direct comparison difficult, we feel that the main problem was technical rather than physiological.

The incidence of a positive airway response to pharmacological challenge depends on the arbitrary dose or concentration of the bronchoconstrictor agent used. By choosing a histamine dose as low as $1 \mu \mathrm{mol}(325 \mu \mathrm{g})$, Duiverman and colleagues found very few responders both in the uncomplicated preterm survivors and in the group with bronchopulmonary dysplasia. At such a dose, only those who had a degree of airway responsiveness comparable with clinical asthma would be identified. One can only infer from their study that long term survivors of bronchopulmonary dysplasia were no more likely than other children of preterm birth to have a degree of airway

Table Clinical details of 10 infants studied

\begin{tabular}{|c|c|c|c|c|c|}
\hline $\begin{array}{l}\text { Case } \\
\text { No }\end{array}$ & $\begin{array}{l}\text { Congenital } \\
\text { heart } \\
\text { disease }\end{array}$ & $\begin{array}{l}\text { Respiratory } \\
\text { syncytial } \\
\text { virus }\end{array}$ & $\begin{array}{l}\text { Assisted } \\
\text { ventilation } \\
\text { given }\end{array}$ & $\begin{array}{l}\text { Ribavirin } \\
\text { given }\end{array}$ & Outcome \\
\hline 1 & Total anomalous pulmonary venous drainage & + & Yes & Yes & Died \\
\hline 2 & Patent ductus arteriosus & + & Yes & Yes & Alive \\
\hline 3 & Double outlet right ventricle & + & Yes & Yes & Died \\
\hline 4 & Total anomalous pulmonary venous drainage & + & No & Yes & Alive \\
\hline 5 & Aortic stenosis, mitral incompetence & + & No & Yes & Alive \\
\hline 6 & Ventricular septal defect & + & No & Yes & Alive \\
\hline 7 & Pulmonary stenosis & + & Yes & No & Alive \\
\hline 8 & Atrioventricular septal defect & & Yes & Yes & Died \\
\hline 9 & Ventricular septal defect & & Yes & No & Alive \\
\hline 10 & Ventricular septal defect & & Yes & No & Died \\
\hline
\end{tabular}


responsiveness as severe as that of the asthmatics. Moreover, with very few positive airway responders in a small study group it would be difficult to show a significant difference statistically, even if such a difference had existed. Additionally, without a reference population, they cannot say whether their findings were normal or abnormal.

In our own study of a cohort of low birthweight children we found that the distribution of a positive airway response to histamine formed a continuum. ${ }^{3}$ At very low doses of histamine very few subjects in either the low birthweight cohort or a reference group showed a positive airway response. On the other hand, a significantly greater proportion of low birthweight children had a positive airway response, at moderate histamine doses, suggesting a shift in the frequency distribution of airway responsiveness. Children with bronchopulmonary dysplasia were slightly more responsive than other low birthweight children.

We agree with the findings of Duiverman and colleagues that very few children with bronchopulmonary dysplasia have a degree of airway responsiveness to histamine similar to recognised asthmatic subjects. Many do, however, show a mild to moderate increase in airway responsiveness when compared with an appropriate reference population. We are therefore unable to agree with their conclusion that 'bronchial responsiveness to histamine in these subjects (bronchopulmonary dysplasia survivors) was normal'.

\section{References \\ 1 Duiverman EJ, den Boer JA, Roorda RJ, et al. Lung function and bronchial responsiveness measured by forced oscillometry after bronchopulmonary dysplasia. Arch Dis Child 1988;63: 727-32. \\ 2 Ahrens $P$, Zielm S, Strover B, et al. Long-term pulmonary and allergic outcome of very low birthweight prematures with and without BPD. Eur J Respir Dis 1988;1(suppl 1):7S. \\ 3 Chan KN, Noble-Jamieson CM, Elliman A, et al. Airway responsiveness in low birthweight children and their mothers.} Arch Dis Child 1988;63:905-10.

$\mathrm{K}$ N Chan and M Silverman Department of Child Health, Royal Postgraduate Medical School, Hammersmith Hospital, Du Cane Road, London W12 OHS

\section{Maternal narcotic abuse and neonatal thrombocytosis}

\section{Sir,}

We read with interest the recent report by AlRoomi et al on maternal narcotic abuse and its effects on newborn infants. ${ }^{1}$ We wish to draw attention to an additional complication, not mentioned in this report, but first regarded by Burstein et al in $1979 .^{2}$ These authors noted significant thrombocytosis in a prospective study of 33 infants of mothers using narcotic drugs. They also specu- lated that platelet microaggregates in these babies may give rise to cerebral infarcts. We have recently seen this complication in two preterm infants admitted to the neonatal intensive care unit. Both mothers were registered heroin addicts on a methadone maintenance programme during pregnancy, and at least one was still using heroin regularly.

\section{Case reports}

CASE 1

A boy, weighing $2320 \mathrm{~g}$, gestational age 31 weeks, had a normal platelet count until day nine when it began to rise reaching an initial peak of $838 \times 10^{9} / 1$ in the third week of life and a second peak of $919 \times 10^{9} / 1$ in the sixth week of life. Other than the mother's substance abuse, there had been no particular antenatal problems and the baby's condition at birth was excellent. On day 4 cranial ultrasound examination showed a periventricular flare, which surprisingly persisted. Cystic degeneration then occurred and at 6 months of age the child had spastic quadriplegia and developmental delay.

CASE 2

A boy, weighing $2280 \mathrm{~g}$, gestational age 32 weeks, had a platelet count which rose from $721 \times 10^{9} / 1$ at the end of the second week to a peak of $969 \times 10^{9} / 1$ on the fourth week and at the time of discharge, at 8 weeks, was still $818 \times 10^{9} / 1$. This baby showed normal growth and appropriate development at follow up to 1 year of age.

In neither baby were there other abnormal haematological indices. Neither baby had perinatal asphyxia but both showed clinical features of narcotic withdrawal in the early neonatal period. Neither infant had received any antiplatelet drugs. Review of cumulative haematology reports of all other babies admitted to the intensive care unit at this time showed that thrombocytosis of this degree was not present in any infants of non drug abusing mothers during the same period of time.

The periventricular leukomalacia in case 1 was unexpected and it must be considered that the thrombocytosis contributed to the ultimate cerebral atrophy. The true incidence of thrombocytosis in babies of narcotic addicted mothers is unknown as not all babies require admission to a neonatal intensive care unit and only in those who have serial full blood examinations over several weeks is this essentially asymptomatic abnormality revealed.

References

1 AlRoomi LG, Davidson J, Evans TJ, Falea P, Howat $R$ Maternal narcotic abuse and the newborn. Arch Dis Child 1988;63:81-3.

2 Burstein Y, Giardina PJV, Rausen AR, Kandall SR, Siljestrom $\mathrm{K}$, Peterson $\mathrm{CM}$. Thrombocytosis and increased circulating platelet aggregates in newborn infants of polydrug users. $J$ Pediatr 1979;94:6.

H M Chambers and R R Haslam Departments of Pathology and Neonatology, Queen Victoria Hospital, Adelaide, Australia 